\title{
The Anti-Nemic Potential of Mushroom against Plant-Parasitic Nematodes
}

\section{Elkhateeb WA ${ }^{1 *}$, Daba GM${ }^{1}$ and Soliman GM²}

${ }^{1}$ Chemistry of Natural and Microbial Products Department, Pharmaceutical Industries Division, National Research Centre, Egypt

${ }^{2}$ Plant Pathology Department, Nematology Unit, National Research Centre, Egypt

*Corresponding author: Waill A Elkhateeb, Chemistry of Natural and Microbial Products

\section{Research Article}

Volume 6 Issue 1

Received Date: February 24, 2021

Published Date: March 15, 2021

DOI: $10.23880 /$ oajmb-16000186 Department, Pharmaceutical Industries Division, National Research Centre, Dokki, Giza, 12622, Egypt, Tel: +201013241936; Fax: +20233370931; Email: waillahmed@yahoo.com

\section{Abstract}

Plant-parasitic nematodes are responsible for huge annual economic loss that is estimated to be more than 215 billion US\$ worldwide due to plants damages caused by nematodes. The root-knot nematode (Meloidogyne spp.) is ranked first in the global list of top ten plant-parasitic nematodes, with wide host range of more than 3000 host plant species and posing a major threat in the cultivation of agricultural, vegetables, and horticultural crops. Such pathogens are commonly controlled using chemical nematicides. However, the risk of using such chemicals on human, animals, and surrounding environment has forced researchers to search for natural, less harmful, and effective nematicidal agents. In this review, we discuss the biological control of nematodes by different microorganisms, stressing on the promising capabilities of some mushrooms such as some species of Pleurotus, Beauveria, Ganoderma lucidum, and Lentinus edodes.

Keywords: Biocontrol; Mushroom; Pleurotus Ostreatus; Plant-Parasitic Nematodes; Anti-Nemic Potential

\section{Introduction}

Sustainable agriculture has become one of the fundamental needs to ensure food security for Humans worldwide. Yet, as a result of population increase, the balance between human and their food supply is not safe. One traditional solution was to increase food via pest control [1,2]. Plant-parasitic nematodes have been present for nearly a billion years [3]. More than 4100 species belonging to different genera of plant-parasitic nematodes have been identified [4]. Such nematodes cause serious annual economic loss worldwide that exceed 215 billion US dollars [5]. Root-knot nematodes (Meloidogyne spp.) are soil-borne, sedentary endoparasite and came in the first position in the top ten list of plant-parasitic nematodes across the world. This genus has widespread, a host range of more than 3000 host plant species and posing a major threat in the cultivation of agricultural, vegetables, and horticultural crops [6-9]. The infection by Root-knot nematodes starts with the penetration of juveniles (J2) plant roots and modifies the vascular cylinder. The migration is aided by a combination of specialized glands secretion of cell-wall-degrading enzymes together with stylet protrusion (mechanical force) at the same time [10]. The J2s do not kill parasitized cells but it induces giant cells generation [11].

There are more than 100 species of Meloidogyne spp. dispersed around the world and they parasitize different plants genera [12]. Meloidogyne incognita, Meloidogyne javanica, Meloidogyne arenaria, and Meloidogyne hapla are the most important species that cause about $95 \%$ of economic losses in cultivated lands [13]. Controlling rootknot nematodes can be performed by applying various strategies such as regulatory, cultural, physical, chemical, 
and biological strategies. However, some limitations and risks appear associated with these strategies [14,15]. The cause of the problematic hardness in controlling nematodes is due to the difficulty in distinguishing the plant infections caused by nematodes with those caused by other pathogens or abiotic factors.They have a wide host range, short periods of high reproductive rate and generation [16]. Although nematicides are the commonest approach for the management of root-knot nematodes but due to the risk to humans and environments presented by using synthetic nematicides hazardous are incited scientists for working on the alternatives to nematicides less harmful control [17].

\section{Biological Control of Nematodes}

Biological control is recently developed approach to controlling nematodes using microorganisms such as fungi and bacteria and their natural product [18-21]. Several biocontrol agents have shown to be able to produce secondary metabolites as antibiotics, toxins, and lytic enzymes. Hydrolytic enzymes such as collagenases, chitinases, proteases and lipase have been related to the nematicides effect in microbial, and were verified as important factor in the degradation process of different chemical components of nematodes during different developmental stages [22]. The clear reason behind their use is that the nematodes biochemical composition during their mobile stages includes collagens and lipids, as well as chitin, and protein in the sedentary stages for tylenchoid nematodes such as Meloidogyne spp.

Generally, the eggshell of the root-knot nematode consists of three main layers:

(a) The outer vitelline layer that gives the structural uniformity of eggs [23];

(b) The middle chitinous layer of the eggshell which contains chitin fibrils embedded in a protein matrix [24] and

(c) The internal lipid layer which preserve the impermeability of the shell [25].

Chitin was detected in found in gelatinous matrix of Meloidogyne javanica [26]. The role of microbial lytic enzymes and their effect on nematode hatching and morphological changes in juveniles, eggs, and eggshells under laboratory condition and efficiency on plant parasitic nematodes biocontrol Figure 1.

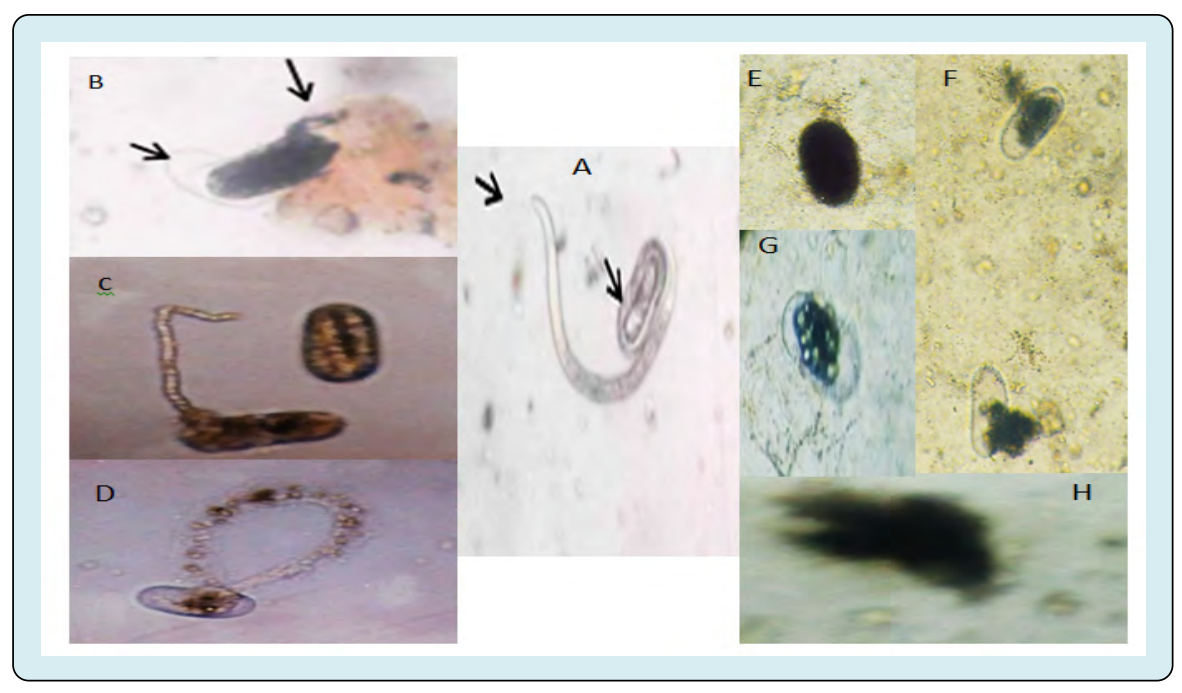

Figure 1 Hatching is observed in the water control; normal juvenile and normal egg-containing J2 (A, arrows). Abnormal juveniles appeared (B and C), Spherical egg (E); eggshells appeared to be destroyed ( $F$ and $G$ ), abnormal hatching and eggs are decomposed (D, H) by microbial enzymes. A photo was taken by Dr. Gaziea at Plant Pathology Department, Nematology Unit, at National Research Centre. Consequently, fungal biological control is an interesting and rapidly developing research area and there is increasing attention in the nematodes biocontrol using fungi [27-29]. Fungi are known to possess a huge diversity of metabolic pathways and they have provided several large classes of commercial compounds, including many antibiotics used in medicine. Consequently, secondary metabolites in fungi could have much potential in their novel structures and nematicidal activities [30-32].

\section{Role of Mushrooms as Eco-Friendly and Less Harmful Nematicides}

Owing to the current focused on eco-friendly approaches for plant disease management caused by nematodes, the present study emphasis on mushroom fungi can serve as a promising source as alternative tools for biocontrol of plant-parasitic nematodes. Basidiomycetous macrofungi possess many biological activities as antimicrobial, antiviral, 


\section{Open Access Journal of Microbiology \& Biotechnology}

mosquito larvicidal, and nematicidal agents [33]. As an example, omphalotin which is a new peptide secreted by the mushroom Omphalotus olearius. Omphalotin has nematicidal activity that is as potent as that obtained by the commercial nematicide ivermectin. Many researches have been made to find potent nematicidal substances that can replace traditional man-made chemical nematicides, few have been developed for wide use [34]. Till now, no fungalbased nematicidal commercial product has been developed [35].

\section{Macromycete Mushrooms as Anti- nematodes Promising Tool}

Macromycete mushrooms are filamentous organisms, lacking chlorophyll, saprobes, which can be seen by the naked eye. They obtain their nutrients from the organic matter in their surrounding environment. They reproduce by the two ways asexually or sexually by spores. These fungi cell wall is composed of cellulose or chitin, and their growth is apical. Macromycetes mushrooms develop fruiting bodies, depend on organic matter in decay and can be parasitic, saprobic, or mutualistic. Such mushrooms can be categorized into edible mushrooms (such as Pleurotus ostreatus) and poisonous ones (such as Amanita abrupta) [36,37]. Mushrooms especially edible mushrooms have many importance concerning their nutritional composition. Edible mushrooms rich source of essential amino acids, vitamins, fibres and others. Mushrooms are a source for many pharmaceutical drugs. Edible mushrooms polysaccharides have antimicrobial and antioxidant activity $[38,39]$. Mushrooms belong to a toxinproducing group of nematophagous fungi. These fungi secrete specific toxins that are capable of paralyzing and/or killing nematodes [40]. Moreover, enzymes are important key factors in the nematode infection and digestion processes by nematophagous mushrooms [41]. Degenkolb and Vilcinskas [42] reported that nematophagous basidiomycetes secrete different toxic nematicidal secondary metabolites.

Oyster mushroom compost is one of the potent compost that is famous for producing nematicidal toxic metabolites. Gray oyster (Pleurotus ostreatus) is one of the commercially produced oyster mushrooms that is known to produce trans2-decenedioic acid which is a toxin secreted by hyphae [43], this toxin paralyzes the nematodes on contact, which allows the hyphae to move into position to colonize and digest the nematode. Till now, only in vitro studies were performed to evaluate the effects of oyster mushroom on nematodes. Mushroom compost of Pleurotus sajorcaju provides promising results in suppressing root-knot nematodes Meloidogyne incognita and has been given a lot of attention by researchers due to their environmentally safe and economically acceptable solution [44]. Xiang and Feng [45], reported the positive effects of Pleurotus ostreatus on the control of the peanut root-knot nematode Meloidogyne arenaria in the greenhouse, and the results of the experiments showed that Pleurotus ostreatus could markedly reduce the infecting number of nematode. Pleurotus ostreatus produces tiny droplets of toxin from minute spathulate secretory cells. When nematodes touching produced Pleurotus ostreatus droplets show a sudden and dramatic response. The head region shrinks significantly. In as little as $30 \mathrm{~s}$, and usually within several minutes, the nematode becomes more or less immobilized but is not killed. Pleurotus strigosus, Pleurotus subareolatus, and Pleurotus cornucopiae behave in a similar way against nematodes [46].

Recently many researchers reported that most edible mushrooms species have nematocidal activity belong to the genus Pleurotus. The anthelmintic activity has been reported form extracts and its fractions obtained from Pleurotus fruiting bodies, mycelium, and degraded substrate. Among the nematicidal biologically active compounds originated from mushroom extracts pentadecanoic acid, octadecadienoic acid, octadecanoic acid, and the terpene $\beta$-sitosterol [47-50]. The capabilities of oyster mushrooms to infect and kill sugar beet cyst nematode Heterodera schachtii was investigated by Palizi, et al. [51], and the potency of Pleurotus ostreatus, P. sajor-caju, P. florida, P. flabellatus, P. ostreatus, P. eryngii and Hypsizygus ulmarius to prey on the cyst nematode was confirmed.

Zhao, et al. [52], mentioned that the culture filtrate of different isolates of Beauveria bassiana and its associated fungus had different levels of nematicidal activities, and the same culture filtrate had selective toxicity against different nematodes. This can be due to the ability of the different species belonging to the genus Beauveria to secrete different potent secondary metabolites as beauvericin, bassianin, bassianolide, beauverolides, bassiacridin, tenellin and oosporein $[53,54]$. Junxianke is a fermentation product produced by Beauveria bassiana, Junxianke is lethal to Ditylenchus destructor, Heterodera glycines and Meloidogyne incognita [55-57], thus Beauveria genus especially Beauveria bassiana have the potentially to applied in prevention of plant parasitic pests and nematodes. However, currently there are insufficient studies on the application of Beauveria in the control of nematode diseases.

Recently some experimental results revealed that the highest hatching inhibition and the juvenile deaths were observed after treatment with the Ganoderma lucidum ethyl acetate fraction followed by that of Lentinus edodes. The maximum inhibition of egg hatching (92.6\%) and juvenile mortality (93.2\%) of Meloidogyne incognita was achieved using $1000 \mathrm{ppm}$ concentration of Ganoderma lucidum bio-active molecules after 72 hours of incubation [58-60]. Nematophagous activities of five mushrooms were 


\section{Open Access Journal of Microbiology \& Biotechnology}

evaluated by Ishizaki, et al. [61], and resulted that five species of saprophytic mushroom including Cyptotrama asprata, Panellus stipticus, Hohenbuehelia reniformes, Resupinatus applicatus, and Pleurotus salmoneostramineus can successfully immobilize and consume the pinewood nematode, Bursaphelenchus xylophilus.

\section{References}

1. Glick B (2012) Plant growth-promoting bacteria: Mechanisms and applications. Scientifica 2012: 963401.

2. Gupta G, Parihar S, Ahirwar N, Snehi S, Singh V (2015) Plant growth promoting rhizobacteria (PGPR): Current and future prospects for development of sustainable agriculture. J Microbiol Biochem Technol 7(2): 96-102.

3. Williamson VM, Gleason CA (2003) Plant-nematode interactions. Curr Opin Plant Biol 6(4): 327-333.

4. Decraemer W, Hunt D (2006) Structure and classification. In: Perry R, Moens M, (Eds.), Plant Nematology. CAB International, Oxfordshire, pp: 3-32.

5. Ferreira JM, Carreira DN, Braga FR, Soares FE (2019) First report of the nematicidal activity of Flammulina velutipes, its spent mushroom compost and metabolites. 3 Biotech 9(11): 410.

6. Bernard GC, Egnin M, Bonsi C (2017) The impact of plant-parasitic nematodes on agriculture and methods of control. Nematology-Concepts, Diagnosis and Control, pp: 121-151.

7. Jones JT, Haegeman A, Danchin EG, Gaur HS, Helder J, et al. (2013) Top 10 plant-parasitic nematodes in molecular plant pathology. Mol Plant Pathol 14(9): 946-961.

8. Liu B, Jiaojiao R, Yan Z, Jingbo An (2015) A new grafted rootstock against root-knot nematode for cucumber, melon, and watermelon. Agron Sus Dev 35(1): 251-259.

9. Gaziea SM, Shereen MAH, Laila HF, El-Hady SE (2020) Efficiency of biological control of root-knot nematodes in infected grapevines seedling by genetic improved bacteria. Plant Archives 20(1): 951-961.

10. Davis EL, Hussey RS, Baum TJ, Bakker J, Rosso MN, et al. (2000) Nematode parasitism genes. Annual Review of Phytopathology 38: 365-396.

11. Molinari S, Fanelli E, Leonetti P (2014) Expression of tomato salicylic acid (SA)-responsive pathogenesisrelated genes in Mi-1-mediated and SA-induced resistance to root-knot nematodes. Mol Plant Pathol 15(3): 255-264.
12. Karssen G, Moens M (2006) Taxonomy and Principal General Root-Knot Nematodes. In: Perry R, Moens M, (Eds.), Plant Nematology. CAB International, Wallingford, UK, pp: 60-90.

13. Eisenback JD, Triantaphyllou HH (1991) Root-knot nematodes: Meloidogyne species and races. Manual of Agricultural Nematology, Marcel Dekker, New York 281286.

14. Javed K, Javed H, Mukhtar T, Qiu D (2019) Efficacy of Beauveria bassiana and Verticillium lecanii for the management of whitefly and aphid. Pak J Agric Sci 56(3): 669-674.

15. Mukhtar T, Kayani MZ (2019) Growth and yield responses of fifteen cucumber cultivars to root knot nematode (Meloidogyne incognita). Acta Sci Pol Hortorum Cultus 18(3): 45-52.

16. Trudgill DL, Blok VC (2001) Apomictic, polyphagous rootknot nematodes: exceptionally successful and damaging biotrophic root pathogens. Annu Rev Phytopathol 39: 53-77.

17. Bhattacharjee R, Dey U (2014) An overview of fungal and bacterial biopesticides to control plant pathogens/ diseases. Afr J Microbiol Res 8(17): 1749-1762.

18. Khalil MS, Allam AF, Barakat A (2012) Nematicidal activity of some biopesticide agents and microorganisms against root-knot nematode on tomato plants under greenhouse conditions. Journal of Plant Protection Research 52(1): 47-52.

19. Szabó M, Csepregi K, Gálber M, Virányi F, Fekete C (2012) Control plant-parasitic nematodes with Trichoderma species and nematode-trapping fungi: The role of chi18-5 and chi18-12 genes in nematode eggparasitism. Biological Control 63(2): 121-128.

20. Soliman GM, Ameen HH, Abdel-Aziz SH, El-sayed GM (2019) In vitro evaluation of some isolated bacteria against the plant parasite nematode Meloidogyne incognita. Bulletin of the National Research Centre 43: 171.

21. Poveda J, Abril-Urias P, Escobar C (2020) Biological control of plant-parasitic nematodes by filamentous fungi inducers of resistance: Trichoderma, mycorrhizal and endophytic fungi. Front Microbiol 11: 992.

22. Islam TM, Hashidoko Y, Deora A, Ito T, Tahara S (2005) Suppression of damping-off disease in host plants by the rhizoplane bacterium Lysobacter sp. strain SB-K88 is linked to plant colonization and antibiosis against 


\section{Open Access Journal of Microbiology \& Biotechnology}

soilborne peronosporomycetes. Appl Environ Microbiol 71(7): 3786-3796.

23. Wharton D (1980) Nematode egg shells. Parasitology 81(2): 447-463.

24. Seong LY, Hoa NX, Wai NK, Suk PY (2015) Role of lytic enzymes secreted by Lysobacter capsici YS1215 in the control of root-knot nematode of tomato plants. Ind J Microbiol 55(1): 74-80.

25. Bird AF, McClure MA (1976) The tylenchid (Nematoda) eggshell: Structure, composition and permeability. Parasitology 72(1): 19-28.

26. Spiegel Y, Cohn E (1985) Chitin is present in gelatinous matrix of Meloidogyne. Revue Nematology 8(2): 179190.

27. Ruanpanun P, Tangchitsomkid N, Hyde KD, Lumyong S (2010) Actinomycetes and fungi isolated from plantparasitic nematode infested soils: screening of the effective biocontrol potential, indole-3- acetic acid and siderophore production. World J Microbiol Biotechnol 26(9): 1569-1578.

28. Alamgir K, Keith W, Helena N (2006) Control of plantparasitic nematodes by Paecilomyces lilacinus and Monacrosporium lysipagum in pot trials. Biocontrol 51(5): 643-658.

29. Moosavi MR, Zare R (2011) Fungi as biological control agents of plant parasitic nematodes. Biol Control 12: 67107.

30. Rodrigue-Kabana R, Canullo GH (1992) Cropping systems for the management of phytonematodes. Phytoparasitica 20: 211-224.

31. Siddiqui ZA, Mahmood I (1996) Biological control of plant parasitic nematodes by fungi: a review. Bioresource Technol 58(3): 229-239.

32. Smedsgaard J, Nielsen J (2005) Metabolite profiling of fungi and yeast: from phenotype to metabolome by MS and informatics. J Exp Bot 56(410): 273-286.

33. Sivanandhan S, Khusro A, Paulraj MG, Ignacimuthu S, Al-Dhabi NA (2017) Biocontrol properties of Basidiomycetes: an overview. J Fungi (Basel) 3(1): 2?

34. Li G, Zhang K, Xu J, Dong J, Liu Y (2007) Nematicidal substances from fungi. Recent Pat Biotechnol 1(3): 212233.

35. Mayer A, Anke H, Sterner O (1997) Omphalotin, a new cycle peptide with potent nematicidal activity from
Omphalotus olearius I Fermentation and biological activity. Nat Prod Lett 10: 25-32.

36. van der Heijden MG, Martin FM, Selosse MA, Sanders IR (2015) Mycorrhizal ecology and evolution: the past, the present, and the future. New phytol 205(4): 1406-1423.

37. Elkhateeb WA, Daba GM, Thomas PW, Wen TC (2019) Medicinal mushrooms as a new source of natural therapeutic bioactive compounds. Egypt Pharmaceu J 18(2): 88-101.?

38. Dong YR, Cheng SJ, Qi GH, Yang ZP, Yin SY, et al. (2017) Antimicrobial and antioxidant activities of Flammulina velutipes polysaccharides and polysaccharide-iron(III) complex. Carbohydr Polym 161: 26-32.

39. Jing P, Zhao SJ, Lu MM, Cai Z, Pang J, et al. (2014) Multiplefingerprint analysis for investigating quality control of Flammulina velutipes fruiting body polysaccharides. J Agric Food Chem 62(50): 12128-12133.

40. Soares FE, Sufate BL, Queiroz JH (2018) Nematophagous fungi: far beyond the endoparasite, predator and ovicidal groups. ANRES 52(1): 1-8.

41. Genier HL, Soares FE, Queiroz JH, Gouveia AS, Araújo JV, et al. (2015) Activity of the fungus Pleurotus ostreatus and of its proteases on Panagrellus sp. larvae. Afr J Biotechnol 14(17): 1496-1503.

42. Degenkolb T, Vilcinskas A (2016) Metabolites from nematophagous fungi and nematicidal natural products from fungi as alternatives for biological control. Part II: metabolites from nematophagous basidiomycetes and non nematophagous fungi. Appl Microbiol Biotechnol 100(9): 3813-3824.

43. Kwok OC, Plattner R, Weisleder D, Wicklow DT (1992) A nematicidal toxin from Pleurotus ostreatus NRRL 3526. J Chem Ecol 18(2): 127-136.

44. Mostafa DM, Allah SF, Awad-Allah EF (2019) Potential of Pleurotus sajor-caju compost for controlling Meloidogyne incognita and improve nutritional status of tomato plants. J plant Science and phytopathology 3(3): 118-127.

45. Xiang HQ, Feng ZX (2000) Effect of Pleurotus ostreatus on dynamics of Meloidogyne arenaria population and control effectiveness. Sci Agr Sinica 34: 27-34.

46. Barron GL, Thorn RG (1987) Destruction of nematodes by species of Pleurotus. Canadian Journal of Botany 65(4): 774-778.

47. Sufiate BL, de Freitas Soares FE, Moreira SS, de Souza 


\section{Open Access Journal of Microbiology \& Biotechnology}

Gouveia A, Monteiro TS, et al. (2017) Nematicidal action of Pleurotus eryngii metabolites. Biocatalysis and Agricultural Biotechnology 12: 216-219.

48. Castañeda-Ramírez GS, Torres-Acosta, JF, Sánchez JE, Mendoza-de-Gives P, González-Cortázar M, et al. (2020) The possible biotechnological use of edible mushroom bioproducts for controlling plant and animal parasitic nematodes. Biomed Res Int 2020: 6078917.

49. Chaurasia P, Bharati S, Kumar S (2020) Recent Studies on Biotechnological Roles of Pleurotus spp. J Biotechnology and Bioprocessing 1(3): 2766-2314.

50. Al-Ani LK, Aguilar-Marcelino L, Salazar-Vidal VE, Becerra AG, Raza W (2021) Role of Useful Fungi in Agriculture Sustainability. In Recent Trends in Mycological Research, Springer, Cham, pp: 1-44.

51. Palizi P, Goltapeh M, Pourjam E, Safaie N (2009) Potential of oyster mushrooms for the biocontrol of sugar beet nematode (Heterodera schachtii). Journal of Plant Protection Research 49(1): 27-33.

52. Zhao D, Liu B, Wang Y, Zhu X, Duan Y, et al. (2013) Screening for nematicidal activities of Beauveria bassiana and associated fungus using culture filtrate. African Journal of Microbiology Research 7(11): 974-978.

53. Quesada ME, Vey A (2004) Bassiacridin, a protein toxic for locusts secreted by the entomopathogenic fungus Beauveria bassiana. Mycol Res 108(4): 441-452.

54. Liu T, Li YF, Chen LJ (2007) The research on the Junxianke that can control north root knot nematode disease. Changjiang Vegetables 2: 48-49.

55. Liu T, Wang L, Duan YX, Wang X (2007) Nematicidal activity of culture filtrate of Beauveria bassiana against Meloidogyne hapla. World J Microbiol Biotechnol 24: 113-118.

56. Liu C, Bin L, Yuxi D (2008) Effects of fermentation filtrate of Beauveria on bio-activities of different nematodes. J Shenyang Agric Univ 39(3): 305-308.

57. Akshaya SB, Krishnamoorthy AS, Nakkeeran S, Poornima K, Sivakumar U (2021) Inhibitory potential of ethyl acetate extract from mushrooms against root-knot nematode (Meloidogyne incognita) 9(1): 528-534.

58. Oka Y (2010) Mechanisms of nematode suppression by organic amendments- A review. Applied Soil Ecology 44(2): 101-115.

59. Bao E (2004) Wild Edible Fungi: A global overview of their use and importance to people. Non-wood Forest Products 17. Economic Botany 60(1): 99-100.

60. Schmitt DP, Sipes BS (1998) Plant-parasitic nematodes and their management. CTAHR Cooperative Extension Service, University of Hawaii, PD 15:4.

61. Ishizaki T, Nomura N, Watanabe K (2015) Screening of mushrooms for nematophagous activity against the pinewood nematode, Bursaphelenchus xylophilus. Nematological Research Japanese Journal of Nematology 45(1): 19-25. 